\title{
Mainline Denominational Switching in Canada: Comparing the Religious TRAJECTORIES OF GROWING AND Declining Church AttendeEs ${ }^{1}$
}

\author{
D. Millard Haskell \\ Stephanie Burgoyne \\ KEVIN N. FLATT
}

Abstract. Based on the survey responses of over 1000 attendees of growing and 1000 attendees of declining Mainline Protestant churches in Canada, this research examines patterns of denominational switching and the characteristics of switchers from both groups. Based on previous Canadian research we hypothesized, among other predictions, that the majority of our Mainline Protestant congregants would never have switched denominations and, of those who had, a plurality would indicate that their previous church was part of another Mainline Protestant denomination. These hypotheses were supported when the responses of growing and declining church attendees were combined but when the responses of the growing church congregants were tabulated separately they were not supported. We show how the switching patterns of the growing Mainline Protestant church congregants are more akin to those of Canadian Conservative Protestant church congregants and we offer explanations as to why this may be the case.

Keywords: Religious Switching; Reaffiliation; Church Growth; Mainline Protestant; Conservative Protestant; Canada

Résumé. Suite à une enquête regroupant plus de 1000 participants provenant d'une église protestante traditionnel au Canada en croissance et de 1000 participants provenant d'une église protestante traditionnel au Canada en déclin, cette recherche a examiné les tendances dans les changements de confessions

1. We extend our thanks and gratitude to the anonymous reviewers whose suggestions made this paper better. We also thank Dr. Kevin Haggerty for his congeniality and editorial support. Finally, a special thanks goes to the clergy and congregants who participated in this study. 
a l'intérieur de chacun des groupes ainsi que leurs caractéristiques. Sur la base de recherche canadienne précédente, nous avons émis l'hypothèse, entre autres prédictions, que la majorité de nos fidèles protestants n'aurait jamais changées de dénominations, et parmi ceux qui avaient changé, une pluralité indiquerait que leur ancienne église faisait partie d'une autre confession protestante. Ces hypothèses ont été soutenues seulement lorsque les réponses des deux groupes confessionnels (soit en croissance et en déclin) étaient combinées, et non lorsque les réponses des participants du groupe confessionnel en croissance étaient compilés séparément. Nous démontrons comment les schémas de mouvance des fidèles de l'église protestante en croissance sont plus similaires à ceux des membres de la congrégation de l'église protestante conservatrice canadienne et nous offrons des explications quant à cette situation.

Mots clés: Mouvances religieuses; ré-affiliation; augmentation de l'assistance a l'église; protestante traditionnelle; protestante conservatrice; Canada

\section{INTRODUCTION}

rowing Mainline Protestant congregations are an anomaly within their overarching denominations. In the United States, national research data shows Mainline congregations are experiencing year-overyear decline in membership and attendance; between 2007 and 2014 alone their number of affiliates dropped about 5 percent (Pew Research Center 2015). Out of a pool of over 30,000 Mainline congregations, Wenger and Reese (2006: 6; Reese 2008) found less than one half of one percent met their criteria for growth. While no comprehensive study has determined what percentage of Canadian Mainline congregations are growing, it is clear that the majority are in steep decline. Canada's four largest Mainline Protestant denominations - the Anglican Church of Canada, Evangelical Lutheran Church in $\mathrm{Canada}^{2}$, Presbyterian Church in Canada, and United Church of Canada - saw membership in their churches drop by about half since peaking in the mid-1960s even while the population of Canada nearly doubled over this same period (Clarke and MacDonald 2011).

This study explores the denominational history of attendees from a purposeful sample (Patton 1990: 169-174) of growing and declining Canadian Mainline Protestant churches. Church by church, it traces the

2. The Evangelical Lutheran Church in Canada uses the term "Evangelical" in the same way it has traditionally been used in Germany, that it, to refer to Protestant churches in the tradition of the Reformation. In this context it does not have the typical connotations of "evangelical"; that is, it does not reflect an overarching Conservative Protestant ethos. 
religious path that brought attendees to their current Mainline congregation. As a means of identifying the unique characteristics of the growing church attendees in the sample, we compare their religious trajectories to those from declining Mainline churches - a group representative of the majority of Mainline Protestant congregants. As detailed in the Methodology section of this paper, over 1000 attendees from growing and over 1000 from declining Mainline Protestant churches were surveyed. The results of the survey demonstrate that the switching patterns of the growing Mainline Protestant church congregants are more akin to those of Canadian Conservative Protestant church congregants. In the Discussion we offer explanations as to why this may be the case.

And while one purpose of this paper is to highlight the differences in the religious trajectories of growing and declining Canadian Mainline church congregants so as to advance understanding of each group, it also has a secondary goal. It seeks to identify the patterns of denominational switching of our sample's attendees and compare them to patterns reported in more general, previous research. Doing so helps achieve greater clarity on the twin issues of religious identification and religious switching in Canada.

\section{Literature Review, Hypotheses and Research Questions}

It is popularly held that most actively religious people, if they persist in their faith, stay in the same denomination in which they were raised (Bibby 2004; 2003; 2002; Demerath and Yang 1998; Roof and McKinney 1987; Sherkat 2001). However, there are those who leave one denomination for another; this process is often referred to as religious switching (Bibby and Brinkerhoff 1973). More formally, the process has been termed reaffiliation, defined by shifts within a particular religion (Stark and Finke 2000: 114). For example, a move within Christianity from Roman Catholicism to Anglicanism would be considered switching/reaffiliation. Typically, a move across religious traditions - that is, from one world religion to another, such as Islam to Christianity-is not considered reaffiliation but instead is termed conversion (Stark and Finke 2000: 114). Religious switching is of interest to those researching religion primarily for the role it plays in the growth and decline of religious organizations. Religious groups, such as churches, that retain current members and enjoy a net gain of members moving from other groups into their own will prosper while, ultimately, churches on the losing end of the switching process will founder. 
In the United States, the most current Gallup poll found that $15 \%$ of Americans say that they have switched from one religious preference to another over the course of their lives (Newport 2006). However, because Gallup's survey left the definition of what constitutes changing "religious preference" to the respondent, the researchers note that in reality the total may be higher as some individuals may not have defined smaller changes, like those between Protestant denominations, as a switch (Newport 2006). Even more recently, America's Changing Religious Landscape survey (Pew Research Centre 2015) found that when Protestantism is treated as a single religious group (comprised of Mainline, Conservative, and Historically Black Protestant denominations), 34\% of American adults of all faiths have changed their religious affiliation from that in which they were raised (Pew Research Centre 2015: 33; cf. Sherkat 2014). The group experiencing the greatest net gains due to "religious switching" is the religiously unaffiliated; "fully $18 \%$ of American adults were raised in a religious tradition and now describe themselves as unaffiliated" (Pew Research Centre 2015: 35; cf. Sherkat 2014). While moving from religious affiliation to unaffiliation is a significant change, to be precise, it tends not to be termed religious switching but, instead, "disaffiliation" (Bromley 1988: 23). Unlike switching where the outcomes are external and easily identified, disaffiliation can manifest as an internal state and in those cases individuals might abandon the beliefs of their religious community but continue to participate in its life and rituals (Brinkerhoff and Burke 1980).

Regarding religious "families" within Protestantism, research in the US from the 1980s and 1990s showed that among those identifying as Mainline Protestants, about 30\% reported having switched in their lifetime while $20 \%$ of Conservative Protestants - also known as Evangelicals - said they had switched (Demerath and Yang 1998; Roof and McKinney 1987; Sherkat 2001). Recent survey data suggests an increase in switching numbers among America's Mainline and Conservative Protestants; $42 \%$ of those now affiliated with the former and $39 \%$ now affiliated with the latter say they were raised outside their current religious family. Looking at the percentages of those who continue to comprise the ranks of Mainline Protestants, 58\% are those raised in that tradition while 20\% are former Conservative Protestants, $12 \%$ are former Catholics, and 6\% are former non-attendees/unaffiliated (Pew Research Centre 2015: 43; cf. Sherkat 2014). Of those comprising the ranks of Conservative Protestants, $61 \%$ are those raised in that tradition while $14 \%$ are former Mainline Protestants, $13 \%$ are former Catholics, and 7\% are formerly unaffiliated Americans (Pew Research Centre 2015: 43; cf. Sherkat 2014). 
Up-to-date data for Canada does not exist; however, previous research demonstrates a culture of switching north of the border that does not mirror the higher levels in the US. This is likely because in Canada a smaller number of denominations control more of the market and historically Canadians have favored stability and the status quo over change (cf. Murphy et al. 1996). Regarding specific findings, Reginald Bibby's (2004; 2003; 2002: 42) research from the early 2000s found that nationally $90 \%$ of those attending Mainline Protestant churches had been raised Mainline Protestant while 10\% had switched in from outside that religious family. Of those who switched in, 3\% were raised Conservative Protestant, 4\% were raised Catholic and 3\% were raised with no religious affiliation (Bibby 2003: 8; 2002: 42). Of those attending Conservative Protestant churches, $67 \%$ had been raised in that religious family, $24 \%$ had switched in from Mainline Protestantism, 3\% had switched from Catholicism, and 5\% had switched from having no religious affiliation (Bibby 2003: 8; 2002: 42; cf. Bibby and Brinkerhoff 1994: 278; Posterski and Barker 1993: 53-54). The low levels of switching he has recorded among Canadian Mainline Protestants compared to Conservative Protestants has led Bibby (2002) to conclude: "switching is the exception not the norm among Mainliners" (41).

In his national switching data, Bibby $(2004 ; 2003 ; 2002 ; 1993)$ does not account for switches between similar denominations (e.g. Anglican to Lutheran, or Baptist to Alliance) but only tracks moves between the "religious families" of Mainline Protestants, Conservative Protestants and Catholics in Canada; thus, he suggests his numbers present overall lower switching totals than what occurs within religious families. He notes: 'I use the term 'religious families'_-versus 'denominations' deliberately. There is undoubtedly a fair amount of movement between [similar] Protestant denominations" (Bibby 2004: 74-75).

In fact, when Bibby (2003; Bibby and Brinkerhoff 1994; 1983; 1973) tracked changes within the "religious family" of Conservative Protestants in a single city, higher switching levels were recorded. Specifically, in addition to his national data on switching, Bibby (2003; Bibby and Brinkerhoff 1994; 1983; 1973), he conducted longitudinal research into the switching patterns of a selection of 20 Conservative Protestant churches in the city of Calgary, Alberta. In his final paper on the topic of Conservative Protestant switching in Calgary, Bibby (2003) summarizes the overall trend he discerned at the close of 30 years of study. $\mathrm{He}$ states that of those who joined the ranks of the Conservative Protestant churches in his sample, over a five-year period about $70 \%$ consistently switch in from other Conservative Protestant congregations, about $15 \%$ are children of current Conservative Protestant attendees, and a final 
$15 \%$ switch in from outside the Conservative Protestant fold. Of the $15 \%$ coming from outside Conservative Protestant churches, just under 5\% come from Mainline Protestant churches, under 3\% come from Catholic churches and most of the remaining are religiously unaffiliated at the time of joining (Bibby 2003:6).

As the findings from Bibby's (2003; Bibby and Brinkerhoff 1994; 1983; 1973) Calgary Conservative Protestant churches demonstrate, in the majority of cases "when switching does take place, it typically involves fairly short theological and cultural trips" (Bibby 1999: 151; cf. 2004: 75; 2002: 41). Elsewhere Bibby (2004; 2002) has argued strongly that all religious switching, regardless of denominational family, is primarily "short trips"; that is, those who do switch from one church to another most often move into religious communities that bear a strong resemblance to the community that they left (Bibby 2004; 2002; 1999; 1993: 32, 36-37; cf. Demerath and Yang 1998; Hadaway and Marler 1993; Marler and Hadaway 1993; Sherkat 2014). Regarding Canadian Protestants specifically he states:

Protestants not only tend to stay within the Protestant category but are also inclined to remain in the Mainline and Conservative "religious families" regardless of how much internal denominational switching may go on (Bibby 2004: 37).

Analyzing national survey data for 1973 to 1990, Hadaway and Marler (1993) confirm the same trend exists in the US, stating, "Americans switch more today than they did in the early 1970s, but when they switch they are more likely to remain in the same larger denominational family" (102; cf. Sherkat 2014). Accounting for this phenomenon, Bibby (1999) explains that most church-goers don't stray, or at least don't stray far, from the denominational family of their youth because "the vast majority of North Americans continue to have psychological, emotional, and cultural links to their parents' religious groups" (152; cf. Hadaway 1990; Sherkat 2014). Exploring Canadian church-goers' levels of comfort with other denomination's worship services, Bibby (1999) found a striking "tendency for denominations to express comfort with groups that are part of their 'religious families'--Mainliners with Mainliners, Conservatives with Conservatives" (155; cf. Bibby 1999: 154).

To sum up, studies of religious switching in Canada show that switching out of one's broader religious family "at least in percentage terms... is relatively rare" (Bibby 2003: 7; cf., 2004: 75). Though switching between Mainline and Conservative Protestant families is increasing, researchers in both Canada and the US concur that most religious switching still involves tiny travels between similar denominations and 
not large leaps from one religious family to another (e.g., Bibby 2003; 2004; 2002; 1999; 1993:32, 36-37; Demerath and Yang 1998; Hadaway and Marler 1993; Marler and Hadaway 1993; Sherkat 2014). Research from the US shows that of those who switch into Mainline Protestantism, the largest single group, at about $20 \%$, has consistently been reaffiliates from Conservative Protestantism (Pew Research Centre 2015: 43; Roof and McKinney 1987: 167; Sherkat 2014). In contrast, data from Canada shows that slightly more reaffiliates to the Mainline family come from Catholicism than Conservative Protestantism, although at 4\% and 3\%, respectively, percentage-wise they are almost equal and neither represent a significant influx to Mainline Protestantism (Bibby 2003; 2002; cf. Bibby and Brinkerhoff 1994). Thus we posit the following hypotheses:

H1a: In our sample of Mainline Protestant congregants, the majority will never have switched denominations; the church they are currently attending will be of the same denomination of the church(es) of their past.

H1b: In our sample of Mainline Protestant congregants, of those who, in the past, regularly attended a church of a different denomination than their current church, a plurality ${ }^{3}$ will indicate that their previous church was part of another Mainline Protestant denomination not a Roman Catholic or Conservative Protestant denomination.

H1c: In our sample of Mainline Protestant congregants, of those who, in the past, regularly attended a church of a non-Mainline denomination, most will indicate that their previous church was Roman Catholic and a near equal, though lesser, number will indicate that their previous church was Conservative Protestant.

As noted in the introduction, the crux of this study is the comparison between the switching patterns of declining Mainline church attendees and growing Mainline church attendees. However, when it comes to growing Mainline Protestant congregations very little research exists; thus it is difficult to generate specific hypotheses in this regard. In fact, when church growth is studied more generally, growing Conservative Protestant congregations and/or denominations are often the sole site of research. Today among social scientists studying religion the claim that theologically Conservative Protestant churches in the United States and Canada are more likely to be the site of numerical growth than Mainline

3. Because Bibby $(2004 ; 2003 ; 2002)$ in his research on switching nationally does not measure switches from one Mainline Protestant denomination to another we are unable to provide a more specific prediction for this hypothesis. 
Protestant churches is uncontroversial as a large body of research has accumulated that demonstrates this fact (e.g., Bibby 2012, 2011, 2004, 2002, 1993, 1987; Bouma 1979; Finke and Stark 2005; Hadaway 2011; Iannaccone 1994; Kelley 1972; Reimer 2003; Tamney and Johnson 1998). Up to this point, only one other Canadian study has focused on growing Mainline congregations (Haskell, Flatt, Burgoyne 2016). That study determined that for every measure of religious belief and practice, the attendees and clergy of the growing Canadian Mainline churches in the sample showed greater levels of theological conservatism than the declining church congregants and clergy (Haskell, Flatt, Burgoyne 2016). Since 2000, a handful of studies have examined the phenomenon in the US (Barna 2003; Finke and Stark 2005:277-278; Finke and Stark 2001; McKinney and Finke 2002; Stark and Finke 2000; Wenger and Reese 2006; cf. Reese 2008). Like the recent Canadian study, each of the American studies found that clergy in the growing Mainline churches tend to be, relative to other pastors in their same Mainline denomination, far more theologically conservative (Finke and Stark 2005:277-278; c.f., Finke and Stark 2001; McKinney and Finke 2002; Stark and Finke 2000; Wenger and Reese 2006; cf. Reese 2008). Further, when religious beliefs of congregants were measured, the growing church attendees possessed theological orientations more similar to those of Conservative Protestants than other Mainline Protestants (Barna 2003; Finke and Stark 2005; Stark and Finke 2000; Wenger and Reese 2006; cf. Reese 2008). In these studies, the hallmark of Christian theological conservatism is a more literal-and less metaphorical - interpretation of scripture, especially the New Testament.

While the extant studies dedicated to growing Mainline Protestant congregations have typically found that these groups possess a conservative theological ethos, none have explored the religious trajectories of the congregants who currently inhabit these congregations. It could be that the conservatism found inside their walls leads them to attract greater numbers of switchers from evangelical denominations; however, just as likely, the denominational signage on their exteriors (and its associated history and traditions) may repel those raised outside of their denominational family. Thus, the current study seeks to build on the finding that growing Mainline congregations have been found to possess a conservative theological ethos asking how such an overarching religious orientation might impact switching. Specifically, the research questions this study seeks to answer are: 
R1a. Do the switching patterns of attendees of growing Mainline Protestant congregations differ from attendees of declining Mainline congregations?

R1b. If so, to what extent and specifically how do attendees of growing Mainline Protestant congregations differ in their patterns of religious switching?

\section{Method}

As detailed in the section above, declining Mainline churches are numerous but growing Mainline congregations are rare. In light of that knowledge, we determined it necessary to follow Patton's (1990) instructions and form a purposeful sample, specifically a "critical case sample" (174). While Patton (1990) uses the singular form "case" in the descriptor of this method, he makes it clear that a "critical case sample" can be comprised of "one or a few critical cases" (174). In such a sample, the cases - the various sites of research - are deemed "critical" because they possess specific characteristics that will provide the most information and have the greatest impact on the development of knowledge (Patton 1990). Patton (1990) notes that under certain circumstances, such as when a phenomenon is rare, it makes strategic sense to pick those sites "that would yield the most information and have the greatest impact on the development of knowledge" (169). Further he suggests that results from a critical case sample have predictive power: "While studying one or a few critical cases does not technically permit broad generalizations to all possible cases, logical generalizations can often be made from the weight of evidence produced in studying a single, critical case"; one should be able to conclude "if it happens there, it will happen anywhere," or, vice versa, "if it doesn't happen there, it won't happen anywhere" (Patton 1990: 174). Our decision to create a purposeful sample was also influenced by the experience of Wenger and Reese (2006) who were forced to resort to a non-random sample when studying US Mainline Protestant congregations that excelled at recruitment of the religiously inactive or unaffiliated. Out of a potential pool of 30,000 congregations, fewer than $0.005 \%$ met their growth criteria (Wenger and Reese 2006: 4).

To form our critical case sample we enlisted a two-pronged approach. We contact regional Mainline denominational offices located in Southern Ontario-from Lake Simcoe in the north to Windsor in the south(e.g., Anglican Diocese of Huron Office, London Presbytery Office of 
the United Church) seeking their assistance in identifying congregations that would fit the criteria of our study. When that strategy generated few results, we also instituted a cold-call campaign directly to churches within the same geographical area. Southern Ontario is the most highly populated and ethnically, politically, industrially, and religiously diverse area of Canada (Government of Ontario 2016). This diversity makes it a highly prized site of research; unlike many other areas of the country where the citizens share a particular uniformity, Southern Ontario approximates the variety that exists in the country as a whole (Haskell et al. 2008). For sheer number of Protestant churches Southern Ontario has no equal in Canada. In fact, the city of Toronto alone holds over 140 United churches, about $5 \%$ of all United Churches in Canada (Yellow Pages Group 2016; United Church of Canada 2016).

To be included in our sample as a growing congregation, a church had to show, via attendance records, annual growth of $2 \%$ or higher over the last ten years. After extensive canvasing of denominational offices and direct calls to churches, 10 congregations were identified as meeting the growing church criteria within the established geographical area. Nine of those ultimately participated: 2 Anglican Church of Canada, 1 Evangelical Lutheran Church in Canada, 4 Presbyterian Church in Canada, and 3 United Church of Canada. Thirteen declining congregations, with aggregate attendance near equal to that of the growing churches in our sample, were also recruited: 3 Anglican Church of Canada, 3 Evangelical Lutheran Church in Canada, 4 Presbyterian Church in Canada, and 2 United Church of Canada. Each of those congregations demonstrated $2 \%$ annual decline or more over the same ten-year period. Churches that had increased in attendance in the last ten years because of an amalgamation with another church did not qualify as growing and were excluded from the study. Our choice of plus or minus $2 \%$ as the marker of growth or decline, respectively, is informed by Lippy's (2006: 7-9) finding that most Protestant churches in the US today fall within such a range. Practically speaking, these numerical boundaries allowed us to exclude plateaued churches while also allowing a margin of error for inaccuracies of attendance records.

The growing and declining churches in the study shared similar external characteristics. About a third of churches from both groups were constructed in the mid to late-1800s; another third were built in the early to mid-1900s, and the final third were built between 1950 and early 2000 s. About half of the growing and half of the declining churches were located in the core of a larger city while one or two others in each group were located in each of the following settings: a rural setting, a small 
city/large town, an older residential area in a larger city, or a new suburban development around a larger city.

To gather data the researchers attended a Sunday service at each of the participating churches and at a point in the service administered a survey to all adult attendees (18 years old or above) achieving almost $100 \%$ compliance. In total, 2255 Mainline attendees completed the survey; 1082 from the declining churches (419 Anglican; 216 Lutheran; 263 Presbyterian; 184 United) and 1173 from the growing (417 Anglican; 69 Lutheran; 437 Presbyterian; 250 United). The instrument consisted of 24 items, several of which had multiple components. We used multiple response category items, fill-in-the-blank, and Likert-scale items. The sections in the survey instrument pertained to: 1) demographic information; 2) religious history; 3) religious practices; 4) religious beliefs/ theological orientation; 5) attendees' perceptions of their congregation; and 6) attendees' perceptions of their church's mission or purpose. Apart from one demographic question about the respondent's age, the analysis and results of this paper focus on responses to questions in section 2 of the survey only. The surveys were coded and the data was analyzed using SPSS statistical software. Two types of statistical analysis were employed. Chi square analysis was used for categorical data and t-tests were used to compare mean scores of interval level data. The religious history questions were coded using a numbered list of possible responses or categories of responses.

While this current study focuses on the religious history and switching patterns of the congregants, an earlier study, using the same sample of churches and currently under review, focused on results from the other sections of the survey. The earlier study also included data from an additional survey of clergy employed at the churches in our full sample. We mention this because a few of the findings from that earlier investigation help explain certain outcomes of this current work. Specifically, our earlier analysis found that clergy and congregants of the growing churches in the sample are more religiously conservative than the declining church clergy and congregants. This was demonstrated, for example, via their strong agreement with survey statements rooted in a more literal interpretation of scripture. Additionally, our other investigation determined our growing churches featured more programs for youth and more contemporary forms of worship compared to the declining congregations. Accordingly, for the purpose of explication, we return to these supplementary findings in the Discussion section, below. 


\section{Results}

Age

The mean age of a Mainline Protestant church attendee in our sample was 58. However, the mean age of the growing church participants was 53, compared with 63 for the declining church participants $(t=13.4035$; $\mathrm{p}<0.0001$ ). Table 1, below, describes the percentage of attendees within prescribed age groups.

Table 1 - Age of Attendees by Growing and Declining Church

\begin{tabular}{|l|l|l|}
\hline Age & Growing Church Attendees & Declining Church Attendees \\
\hline From 18 to 40 & $24.5 \%$ & $10.9 \%$ \\
\hline From 41 to 60 & $37.6 \%$ & $24.9 \%$ \\
\hline Over 60 & $34.8 \%$ & $59.8 \%$ \\
\hline
\end{tabular}

\section{Year of first attendance}

Congregants were asked the year they started attending their present church. Not surprisingly, growing churches had more new attendees joining in the last five, ten, and even 20 years than declining churches. Table 2, below, describes the percentage of attendees who reported joining in each time interval $\left(\chi^{2}=187.03 ; p<0.0001\right)$. The majority of declining church attendees joined their current church 20 years ago or more; the majority of growing attendees joined their current church in the last ten years.

Table 2 - Beginning Year at Present Church

\begin{tabular}{|l|l|l|}
\hline Year of first attendance & Growing Church Attendees & Declining Church Attendees \\
\hline $2009-2013$ & $41.5 \%$ & $15.8 \%$ \\
\hline $2004-2008$ & $17.6 \%$ & $12.0 \%$ \\
\hline $1999-2003$ & $12.0 \%$ & $9.8 \%$ \\
\hline $1994-1998$ & $6.7 \%$ & $9.7 \%$ \\
\hline Before 1994 & $22.2 \%$ & $52.7 \%$ \\
\hline
\end{tabular}




\section{Switching-All Mainline respondents}

On the survey, several key questions focused on the religious switching of the respondents. All 2255 Mainline congregants in our sample-1173 from growing Mainline churches and 1082 from declining - were asked to list churches they had regularly attended in the past that they had considered their "home congregation." Past home congregations were identified by denomination and each unique denomination was coded. Below, tabulated responses are presented first in aggregate-representing all survey participants, growing and declining church attendees combined. Next, responses are divided and presented according to growing and declining church congregants. Finally, the responses of new congregants of growing and declining churches (those having joined their current congregation in the last five years) are highlighted.

Based on the combined responses of those from growing and declining churches, a majority of the Mainline congregants in our sample, $57.7 \%$, had never switched denominations. Another $16.2 \%$ of all congregants reported switching from a church in a different Mainline denomination. In total, $73.9 \%$ of the Mainline congregants in our study had always attended a church within the Mainline Protestant religious family. Conversely, $11.3 \%$ of all had, prior to their current Mainline church, exclusively attended churches within Conservative Protestant denominations and 5.5\% had exclusively attended Roman Catholic churches before they switched to their current Mainline church. Interestingly, some respondents reported serial "denomination hopping" prior to taking root at their current Mainline church: $4.6 \%$ had, at various points in their lives, regularly attended a mix of other Mainline and Conservative Protestant denominations; about 1\% had, at some point, regularly attended Conservative Protestant and Roman Catholic churches and another 1\% Catholic and other Mainline Protestant churches. Less than $.5 \%$ had regularly attended Roman Catholic, Mainline and Conservative Protestant churches before settling at their current Mainline church. Finally, $1.9 \%$ of all respondents had attended non-Protestant and nonRoman Catholic places of worship prior to attending their current Mainline Protestant church.

\section{Switching-Growing church congregants versus declining church congregants}

When broken into their respective groups, switching levels between growing and declining church congregants differed significantly with attendees of growing churches more likely to have previously attended 
another church of a different denomination than congregants of declining churches $\left(\chi^{2}=87.352, \mathrm{p}<0.0001\right)$.

In fact, growing church attendees were as likely to have switched denominations as not. Of the 1173 growing church attendees, $45.3 \%$ had never switched denominations while $54.7 \%$ indicated they had been a regular congregant in a church of another denomination. Of the 1082 declining church congregants, $64.9 \%$ had never switched denominations while $35.1 \%$ indicated they had been a regular congregant in a church of another denomination. Switchers within the growing and declining churches also differed greatly regarding where they had made their religious home prior to settling at their current Mainline congregation $\left(\chi^{2}=\right.$ $147.658, \mathrm{p}<0.0001)$. Of the over half of growing church attendees who did switch, $17.1 \%$ had, prior to their current Mainline church, exclusively attended churches in other Mainline Protestant denominations. Thus, $62.4 \%$ of growing church congregants had always attended churches within the Mainline religious family. On the other hand, slightly more switchers into the growing churches-19.4\%--had attended churches in Conservative Protestant denominations exclusively, while 5.9\% had exclusively attended Roman Catholic churches (see Table 3 for all categories).

Of the $35.1 \%$ of declining church attendees who had switched, just under half of those- $16 \%$ - had made the small step from another Mainline denomination; thus, $80.9 \%$ of all declining church attendees were either those who had never switched (64.9\%) or those who had moved from churches in other Mainline denominations (16\%). Just $6.4 \%$ of all declining church attendees had come from an exclusively Conservative Protestant background and 5.4\% from an exclusively Roman Catholic background (see Table 3 for all categories). 
Table 3 - Previous Affiliations of Religious Switchers in Growing and Declining Churches

\begin{tabular}{|l|l|l|}
\hline $\begin{array}{c}\text { Denomination From Which } \\
\text { They Switched }\end{array}$ & Growing Church Attendees & \multicolumn{1}{|c|}{$\begin{array}{c}\text { Declining Church } \\
\text { Attendees }\end{array}$} \\
\hline No Switch & $45.3 \%$ & $64.9 \%$ \\
\hline Other Mainline Protestant & $17.1 \%$ & $16 \%$ \\
\hline Conservative Protestant & $19.4 \%$ & $6.4 \%$ \\
\hline Roman Catholic & $5.9 \%$ & $5.4 \%$ \\
\hline $\begin{array}{l}\text { Other Mainline Protestant and } \\
\text { Conservative Protestant }\end{array}$ & $7.8 \%$ & $2.7 \%$ \\
\hline $\begin{array}{l}\text { Combined } \\
\text { Roman Catholic Combined }\end{array}$ & $1.3 \%$ & $1.2 \%$ \\
\hline $\begin{array}{l}\text { Other Mainline Protestant and } \\
\text { Roman Catholic Combined }\end{array}$ & $1.4 \%$ & $.8 \%$ \\
\hline $\begin{array}{l}\text { Other Mainline Protestant, } \\
\text { Roman Catholic Combined }\end{array}$ & $0.6 \%$ & \\
\hline $\begin{array}{l}\text { Other (non-Protestant and non- } \\
\text { Roman Catholic) }\end{array}$ & $1.2 \%$ & $1.3 \%$ \\
\hline
\end{tabular}


Switching - New attendees of growing and declining Mainline churches

Of the 2225 Mainline congregants in our sample, 601 were new attendees having joined their current church within the last five years (2009 to 2013). Of the new attendees, 452 settled in to a growing church and 149 into a declining congregation. Considered as a single group, $37.8 \%$ of the new congregants had never switched denominations while $62.2 \%$ indicated they had been a congregant in a church of another denomination. However, divided into their sub-groups, new attendees of growing and declining churches present significantly different switching histories.

A chi square test verified the significant difference in the history between new attendees in growing and declining churches $\left(\chi^{2}=68.683, p\right.$ $<0.0001)$.

Almost 70\% (68.1\%) of new attendees in the growing Mainline congregations had switched; that is, they had regularly attended a church of another denomination prior to attending their current Mainline church. Furthermore, self-reported accounts of their recent religious history showed about two thirds (63.9\%) of them moved from active attendance at one church to active attendance at their current church without a lapse in between. Equally interestingly, 28.5\% - a plurality of the growing church new attendees switching in - had, prior to their current Mainline church, attended churches in Conservative Protestant denominations exclusively. Another $17.5 \%$ had, prior to their current Mainline church, exclusively attended churches in other Mainline Protestant denominations while $6.2 \%$ had exclusively attended Roman Catholic churches (see Table 4 for all categories).

While only half $-49.4 \%$ - of new attendees at our growing churches had always resided within the Mainline religious family, three-quarters (75.2\%) of new attendees at declining churches had a consistent history within Mainline churches. Specifically, 55.7\% reported having never switched denominations while $19.5 \%$ had, prior to their current Mainline church, attended a church within another Mainline denomination. Ten percent of all declining church new attendees had, prior to their current Mainline church, attended churches in Conservative Protestant denominations exclusively while $4 \%$ had exclusively attended Roman Catholic churches (see Table 4 for all categories). Though these attendees were new to their current church, catalogues of their recent religious history showed most had never experienced a break in their religious service attendance.

Hypothesis 1a proposed that in our sample of Mainline Protestant congregants, the majority will have never switched denominations; the 
church they are currently attending will be of the same denomination of the church(es) of their past. That hypothesis was supported. However, the slightly larger number of switchers versus non-switchers among the growing church attendees and the significant propensity for new attendees of growing churches to be switchers was an unexpected result in light of the overall, lower Mainline switching rates of previous Canadian studies. In the Discussion section of this paper we consider this phenomenon.

Hypothesis $1 \mathrm{~b}$ proposed that in our sample of Mainline Protestant congregants, of those who, in the past, regularly attended a church of a different denomination than their current church, a plurality will indicate that their previous church was part of another Mainline Protestant denomination not a Roman Catholic or Conservative Protestant denomination. That hypothesis was supported. However, among the growing church attendees generally and even more so among the new attendees of the growing churches, a plurality of those who switched had previously attended Conservative Protestant churches exclusively. Previous Canadian studies of switching have never identified this phenomenon. Thus, in the Discussion section of this paper we offer some possible explanations. 
Table 4 - Previous Affiliations of Switching New Attendees in Growing and Declining Churches

\begin{tabular}{|l|l|l|}
\hline \multicolumn{1}{|c|}{$\begin{array}{c}\text { Denomination From Which } \\
\text { They Switched }\end{array}$} & \multicolumn{1}{|c|}{$\begin{array}{c}\text { Growing Church New } \\
\text { Attendees }\end{array}$} & $\begin{array}{c}\text { Declining Church New } \\
\text { Attendees }\end{array}$ \\
\hline No Switch & $31.9 \%$ & $55.7 \%$ \\
\hline Other Mainline Protestant & $17.5 \%$ & $19.5 \%$ \\
\hline $\begin{array}{l}\text { Conservative Protestant } \\
\text { Roman Catholic }\end{array}$ & $28.5 \%$ & $10 \%$ \\
\hline $\begin{array}{l}\text { Other Mainline Protestant and } \\
\text { Conservative Protestant } \\
\text { Combined }\end{array}$ & $11.2 \%$ & $4 \%$ \\
\hline $\begin{array}{l}\text { Conservative Protestant and } \\
\text { Roman Catholic Combined } \\
\text { Roman Catholic Combined } \\
\text { Other Mainline Protestant, }\end{array}$ & $1 \%$ & $.7 \%$ \\
\hline $\begin{array}{l}\text { Other Mainline Protestant and } \\
\text { Roman Catholic Combined } \\
\text { Roman Catholic) }\end{array}$ & $1.5 \%$ & $2 \%$ \\
\hline
\end{tabular}

Hypothesis 1c held that in our sample of Mainline Protestant congregants, of those who, in the past, regularly attended a church of a nonMainline Protestant denomination, most will indicate that their previous church was Roman Catholic and a near equal, though lesser, number will indicate that their previous church was Conservative Protestant. That hypothesis was not supported; in fact, in all cases those who had switched from outside the Mainline Protestant religious family most often moved 
from Conservative Protestant churches. Furthermore, only among the declining church attendees were the levels of switching from Roman Catholicism close to those from Conservative Protestantism. When responses of growing and declining church attendees were considered together, or the responses of growing church attendees (at large and those new) were considered separately, switchers from Conservative Protestantism were significantly higher than those from Roman Catholicism. We explore this matter in our Discussion section.

\section{Discussion}

Before reflecting on what we identify as the most significant aspects of our results, we must acknowledge the limitations of our study. Its most important limitation is the non-random sampling technique. As noted in the Method section, we needed to adopt a purposeful (Patton 1990: 169) rather than random sampling approach in order to gather an adequate pool of growing churches. Previous researchers studying similar phenomena in the US also found this to be necessary (Wenger and Reese 2006). Given its ability to yield information from uncommon phenomena we believe our critical case sampling approach is well suited to investigating potential differences between growing and declining churches. However, our data set as a whole does not - and is not meant to - mirror the larger population of Canadian Mainline Protestant churches, since growing churches are greatly overrepresented in our sample. At best our results can only provide logical generalizations not statistical generalizations (Patton 1990: 174). In terms of the logical generalizations we can provide, their validity finds some support in the fact that they are broadly consistent with what others have determined when studying growing and declining Mainline Protestant congregations in the US (e.g., Barna 2003; Finke and Stark 2005: 277-278; Finke and Stark 2001; McKinney and Finke 2002; Stark and Finke 2000; Wenger and Reese 2006; cf. Reese 2008).

Another limitation of this study is its restricted geographical reach. Having focused solely on Southern Ontario, our results may not be representative of other Canadian regions. However, as detailed in the Methodology of this paper, among sites of research, Southern Ontario is unparalleled in its ability to reflect the diversity one sees across Canada. Thus, more so than most other regions, the idea that "what one sees here, one is likely to see elsewhere in the country" applies.

Now, regarding our results, in the growing Mainline Protestant churches of our study, two-thirds of attendees were under age 60 and 
one-third were over. In our sample's declining churches, those percentages were reversed. Interestingly, the average age of our growing church attendees is closer to what one finds among Canadian evangelical church attendees (VanGinkel 2003); conversely, the average age among our declining church attendees is what others found to be typical for other Canadian Mainline Protestant congregations (Armstrong 2011). It is likely that the significant year-over-year influx of new congregants to growing churches - $41.5 \%$ saying they joined in the last five years - is responsible for this overall lower mean age. The more new attendees a church takes in overall, the more likely it is to take in younger congregants.

Regarding specific switching trajectories, if our study had only examined the switching patterns of attendees of declining Mainline Protestant churches, our results would have closely aligned with past trends identified by Bibby $(2004 ; 2003 ; 2002 ; 1993)$. For example, his research on religious switching suggests the majority of Mainline Protestant congregants in Canada have never switched denominations. Of the minority of Mainline congregants who do switch into their current church from elsewhere, most will have previously attended churches within other Mainline Protestant denominations. In fact, Bibby's (2004; 2003; 2002) national statistics on switching from the beginning of this century show $90 \%$ of congregants worshipping in Canada's Mainline Protestant churches have always attended churches within the Mainline Protestant religious family. Similarly, our results show a majority $(65 \%)$ of our declining Mainline Protestant church congregants have never switched and those who did primarily transferred from exclusive attendance at other Mainline Protestant denominations (16\%); thus, about $81 \%$ of our declining church congregants had always attended churches within the Mainline Protestant religious family. More recent studies out of the US (Newport 2006; Pew Research Center 2015; cf. Hadaway and Marler 1993) have determined that switching levels among Protestants have increased gradually over the last decade; therefore, the $9 \%$ increase between Bibby's $(2004 ; 2003 ; 2002)$ data on switching among Mainliners-from more than a decade ago--and ours is not unexpected or unusual.

When one looks only at the new attendees of the declining churches (those having joined in the last five years), a close affinity to Bibby's (2004; 2003; 2002) data can still be seen, although with some slight, and anticipated, differences. Once more we see that a majority (55.7\%) had never switched and those who did came primarily from exclusive attendance at other Mainline Protestant denominations (19.5\%); in total, about $75 \%$ had always attended churches within the Mainline Protestant religious family. While a majority had never switched, the propensity to switch is about $10 \%$ greater among the new congregants than among 
declining church attendees generally. Again, observations of increased switching levels over the last few decades have been recorded in the US and this suggests the same phenomenon here in Canada.

Why Bibby's (2004; 2003; 2002) results for Mainline Protestant switching nationally so closely match the results generated by the congregants of declining Mainline Protestant churches in this current study can likely be explained in terms of the Mainline Protestant respondents populating Bibby's $(2004 ; 2003 ; 2002)$ national sample. First, it must be stressed, that the significant presence of congregants of growing Mainline churches in our study sets it apart from what one would typically encounter nationally. Growing Mainline churches are a rare exception; the vast majority of Mainline Protestant churches in North America are declining. It is therefore correct to say the "typical" Mainline Protestant church is a declining one. Our own experience conducting this study is instructive: within a $300 \mathrm{~km}$ radius comprising the most populated portion of Canada, we were only able to compile a critical case sample of nine growing Mainline congregations (cf. Wenger and Reese 2006). Given how rare it is to come across a growing Mainline congregation in Canada (even when one is expressly looking), we might surmise that in his national research on switching, Bibby's (2004; 2003; 2002) sample of Mainline Protestant respondents came primarily (if not exclusively) from declining churches. Thus, it is not surprising that the switching histories of our declining church respondents and Bibby's respondents align so closely.

What is surprising is the extent to which the switching patterns of our study's growing Mainline Protestant church attendees do not align with previous Canadian outcomes and expectations. Past findings suggest that some interdenominational switching can be expected between Canada's four largest Mainline Protestant denominations but typically "switching is the exception not the norm among Mainliners" (Bibby 2002: 41). And yet, more than half $(55 \%)$ of our study's growing church congregants report that they have switched either interdenominationally or across religious families. That number rises to almost $70 \%$ (68.1\%) when examining new members of growing churches. All this is to say, switching for these particular congregants appears to be "the norm."

And while past research has suggested it would not be unlikely to find moderate levels of interdenominational switching among Mainliners as "people who are United, Anglican, Lutheran, and Presbyterian appear to have something of a free trade agreement" (Bibby 2004: 75), it has been uncompromisingly argued that switching out of one's broader religious family, "at least in percentage terms... is relatively rare" (Bibby 2003: 7; cf., 2004: 75). But switching outside of religious family was not rare for 
the attendees of our growing Mainline Protestant churches. Surprisingly, close to $40 \%$ (37.6) of those attendees transferred in from outside the Mainline Protestant religious family, a number almost four times greater than what past research found for Mainline Protestants in general. Revealing a potential upward trend, half $(50.6 \%)$ of the new attendees in those churches reaffiliated from non-Mainline Protestant churches. In our sample of growing church congregants, perhaps most surprising of all was the ratio of switchers from other Mainline Protestant churches $(\mathrm{N}=17.1 \%)$ versus those from Conservative Protestant churches $(\mathrm{N}=$ $19.4 \%$ ). While the difference is only slight when all growing congregants - old and new-are considered, when the focus is narrowed to just new attendees the difference is great. Almost twice as many new attendees of growing churches reaffiliated from Conservative Protestant churches than from other Mainline Protestant churches (17.5\% vs. $28.5 \%)$.

To be sure, the switching patterns of the growing Mainline Protestant church attendees in our study do not align with what past research has determined typically occurs in Mainline congregations. Instead, as keen observers may have already noticed, their switching patterns more closely approximate what previous studies have found in Canadian Conservative Protestant churches. Bibby (2004; 2003; Bibby and Brinkerhoff 1994) has shown that Conservative Protestants are more apt to make both little and big switches. In his national survey data, he found that attendees of Canadian Conservative Protestant churches switch between religious families at rates three times higher than those in Mainline Protestant churches (2004; 2003; cf. Bibby and Brinkerhoff 1994); moreover, his Calgary survey data showed that about $70 \%$ of congregants of Conservative Protestant churches report inter-denominational switching (Bibby 2003).

If the switching patterns of our growing Mainline Protestant church congregants are similar to the switching patterns found in Canadian Conservative Protestant churches, it is likely because the growing Mainline Protestant churches that they attend resemble Conservative Protestant congregations. As noted in the Methodology section of this paper, the church attendees in this current study - as part of a larger research initiative - were also surveyed regarding their religious beliefs and practices (the analysis of which forms the content of another paper) (Haskell, Flatt, Burgoyne 2016). In that first examination we found congregants and clergy of growing churches possessed greater levels of theological conservatism than declining church congregants and clergy in the sample (Haskell, Flatt, Burgoyne 2016). Pastor survey responses also showed that programmatically these growing churches offered more for 
youth and more often used contemporary worship styles, such as the use of guitars and drums. Similarly, as mentioned in the Literature Review, American studies of growing Mainline Protestant congregations have also identified theological conservatism as one of their key traits (Barna 2003; Finke and Stark 2005: 277-278; Finke and Stark 2001; McKinney and Finke 2002; Stark and Finke 2000; Wenger and Reese 2006; cf. Reese 2008). More generally, research from the US has found links between the use of drums and guitars during worship and congregational growth (Hadaway 2011).

Knowing that the growing Mainline Protestant churches of our sample closely resemble Conservative Protestant churches compels us to reinterpret whether our results disprove Bibby's (2003: 7) claim that in Canada switching between religious families "at least in percentage terms... is relatively rare" (cf. 2004; Bibby and Brinkerhoff 1994; Demerath and Yang 1998; Hadaway and Marler 1993; Marler and Hadaway 1993). On the surface, our finding that almost twice as many new congregants reaffiliated from Conservative Protestant churches $(28.5 \%)$ than from churches in other Mainline denominations (17.5\%) seems to suggest a new trend: a significant increase in switching between religious families. But this is not so. In reality, these new attendees-and, for that matter, the other growing church attendees with past histories in Conservative Protestant churches - were making the less drastic step of transferring from one conservative theological community to another. The growing churches in our sample appear able to straddle the "religious family border" and keep a foot in both Mainline and Conservative Protestant camps. This, in all likelihood, contributes to their appeal and growth - an idea we pursue more fully in later paragraphs.

Our finding that erstwhile Conservative Protestants are switching into theologically conservative Mainline congregations, reaffirms but also adds a particular nuance to the assertion of Bibby (2004) and others (e.g., Bibby and Brinkerhoff 1994; Demerath and Yang 1998; Hadaway and Marler 1993; Marler and Hadaway 1993) that those who switch out of one church tend to switch into another in the same religious family. Regarding nuance, our finding shows that the traditional or standard ways of defining "religious family" according to denominational monikers should be broadened to include the theological character at the level of a congregation. Family resemblance can extend beyond family name; Sherkat's (2014) recent claim that "there is no uniform Mainline Protestantism" is evidenced here (175).

While we propose that the similarities our growing Mainline congregations share with Conservative Protestant congregations makes them appealing to those transferring from other Conservative Protestant 
churches, we now also explore the opposite dynamic. That is, it could be the growing Mainline churches in our sample are appealing to Conservative Protestant switchers because they are somehow different from their previous congregations. Clearly, those attendees of our growing churches with previous histories in Conservative Protestant congregations could have switched from their last Conservative Protestant congregation to another Conservative Protestant congregation but they did not. With full cognizance, they chose to switch to a Mainline Protestant church. Why? We offer several explanations.

It could be, for many, their decision to switch from a Conservative to Mainline Protestant congregation was to some degree practical, not theological. Perhaps their new Mainline church was geographically more convenient, or the preaching or music was slightly more engaging, or the people seemed friendlier, or a mix of these. Recent studies have shown that among active churchgoers brand loyalty - that is, lifelong allegiance to a single "named" denomination -is weakening. Since the 1970s in the US there has been a 400\% increase in Protestants claiming "non-denominational" as their religious affiliation (Stetzer 2015). In Canada, Protestants identifying generically as "simply Christian" have also been on the rise (Clarke and Macdonald 2007). It stands to reason, when denominational allegiance is de-emphasized other more individualistic, practical motives for church selection can take precedence. "As long as my internal needs are being met," so the thought process goes, "the name on the external signage matters little." That being said, we feel it must be emphasized that the appeal of practical factors only extends so far. Had these growing Mainline churches not embodied a conservative theological ethos it is unlikely closer geographical proximity, lively music, or other such elements would have drawn and kept their conservative-leaning attendees.

Of course, those in our sample who switched from a Conservative Protestant congregation may have done so in reaction to something they came to view as unpleasant about their former faith tradition. External pressures or internal pressures could be at play.

At the beginning of the $20^{\text {th }}$ century in his book The Social Sources of Denominationalism, H. Richard Niebuhr (1929) introduced the idea that congregants of churches in greater tension with the rest of society (like Conservative Protestants) eventually seek out more socially acceptable congregations as they attain higher status. While this highly evolutionary view has been considerably modified since its publication (cf. Martin 1962), its tenet that individuals, over time, tend to desire a faith that is less at odds with the dominant culture around them still has strong scholarly support (Stark and Finke 2000: 204-205). Stark and Finke (2000) 
clarify the motivation for such a shift to lower social tension stating adherents of "strict faiths"- those that promote more conservative beliefs and values - pay a greater social price because the rules of their religion "hinde[r] their association with others of their class" (204). Among Christian faith groups in Canada, Conservative Protestants are the most likely to suffer from social stigma. Almost one third of Canadians state they would feel uneasy around a Conservative Protestant (Bibby, cited in George 2006); this number doubles to about two thirds when those Canadians polled are religious "nones" (Angus Reid Institute 2015). Other research shows political, media, and academic elites in Canada who are not evangelicals themselves tend to feel disdain for this faith group (Haskell 2009; Yancey, Reimer and O'Connell 2015). Given that a significant portion of the population, including cultural leaders, view Conservative Protestants and their beliefs as objectionable, it seems likely that at least some of those saddled with the Conservative Protestant label — because of the church they attend - might succumb to external pressures and seek out another congregational home. Switching from a Conservative to a Mainline Protestant church allows them to abandon a personal religious label that others in the population view negatively. Undeniably, the growing Mainline churches in our sample offer a particularly good bargain for the would-be Conservative Protestant longing to switch. More so than typical Mainline churches, our growing churches allow Conservative Protestants switchers to conserve the religious capital they acquired over a lifetime (Stark and Finke 2000: 121). Put most simply, they provide a unique opportunity for those more interested in switching religious labels than switching core religious convictions.

If fear of social stigma is not the root of our Conservative to Mainline Protestant switches, internal personal conflict may be the answer. In the US, it is reported that some practicing Christians, especially Conservative Protestants of young-adult age and lower, feel conflicted between certain ideologies doggedly promoted by their faith community and those promoted by society-at-large (and held by them personally). This internal conflict causes them to leave their home congregation but not necessarily their religious faith (Kinnaman 2011; cf. Smith and Snell 2009). Kinnaman's (2011) US study identified the major points of disconnection. Among other elements, those who were personally conflicted felt leaders and other members of their faith community promoted a Christian faith that was anti-science, repressive sexually, too exclusive, and unwelcoming of doubt. Thiessen's (2015) study of religious commitment and practice in Canada similarly concluded that elements such as these are among the reasons those raised in a particular Christian denomination might chose to leave it. 
These findings are instructive. While we did not find direct evidence of this phenomenon, we can imagine people raised in a Conservative Protestant church who largely accept the traditional doctrines of Christianity but feel uncomfortable with their home church's emphasis on specific theological matters that they personally deem peripheral, or worse, objectionable to their faith. For such people a Mainline Protestant church with a conservative theological character-like the growing churches in our sample - presents a perfect compromise and, for them, the appeal would be great. Reflecting Mainline history and sensibilities, such a church is less likely to do battle at the intersection of social values and religious belief (at least not from the pulpit). However, true to its conservative theological nature it insists on reinforcing the core Biblical claims surrounding God and Jesus.

In his theoretically musings on church growth and decline Stark (e.g., 1996; Finke and Stark 2005; Stark and Finke 2000) advances the proposition that religious groups are "likely to succeed to the extent that they maintain a medium level of tension with their surrounding environment - are strict but not too strict" (1996: 137). "Too strict," as Stark (1996; Stark and Finke 2000; Finke and Stark 2005) envisions it, is a moving target that changes as cultural norms change. Beliefs and values that were "just strict enough" in the recent past, could be deemed "too strict" today. Reflecting on the dual nature of the growing Mainline churches in our sample and their ability to incorporate elements of both Mainline and Conservative Protestantism, it would seem they have found the "sweet spot" and are an example of what Stark (1996) means when he employs the somewhat vague descriptor "strict but not too strict" (137). And while his specific proposition seems to apply here, it is beyond the scope of this discussion to fully evaluate the extent to which our findings support Stark's "strict church thesis" more generally.

Having addressed the potential reasons why the growing Mainline Protestant churches in our sample held strong appeal to switchers from Conservative Protestant congregations, we turn our attention to whether the switching patterns identified in our study might lend support to one of Bibby's (2011) most recent theoretical claims and we conclude with a word or two about church growth in general.

In the last few years Bibby (2011) has argued that Canada is experiencing a polarization when it comes to religious belief. Increasingly, Canadians are gravitating to opposite ends of a religious spectrum marked by greater religious belief and practice on one end and no religious belief or practice on the other - the "mushy middle," marked by casual religious devotion, is being vacated (Bibby 2011). According to Bibby's (2011) model, Canadians choosing religion gravitate to churches and other reli- 
gious bodies that position themselves away from the middle and closer to the religiously rigorous end of the spectrum. In a certain respect, our growing Mainline churches affirm Bibby's (2011) claim, given that they draw a significant and diverse mix of switchers from other Mainline and Conservative Protestant congregations. It seems that their overall positioning toward the conservative end of the religious spectrum, and not their denominational affiliation, contributes most to their attractiveness and numerical success.

However, in another respect our growing Mainline churches fail to support Bibby's (2011) polarization thesis, if by polarization he means that both ends of the spectrum - the devoutly religious end and the irreligious end - are experiencing dynamic growth at the expense of the "mushy middle." Nothing in our data suggests our growing churches are flush with new attendees switching in from previous lives of low or little religious activity. In fact, our data indicate the opposite, most are coming from active participation at other churches. Like our findings, past research confirms it is not "tepid" religious adherents - those with weak ties to their current church — who are most likely to switch; instead, it is the religiously active who are most prone (Hadaway and Marler 1993; Newport 2006). Elsewhere, Bibby (2002: 41) himself agrees that it tends to be the ranks of the most devout who are prone to switch. In fact, findings from his sample of switchers from Calgary Conservative Protestant churches led him to conclude that the religiously lax or indifferent seldom switch from the outside into a denominational home. He states:

"for all the rhetoric about evangelism, outreach, and seeker-sensitive ministries, Canadians who are not actively involved in churches are seldom recruited..." (Bibby 2002: 41).

Interestingly, while Bibby's (2011) newer, polarization thesis fails to find unequivocal support here, his earliest and best known theory, "the circulation of the saints" is strongly confirmed (Bibby 2003; Bibby and Brinkerhoff 1993; 1983; 1973). The theory states that conservative Christian churches grow primarily through retention of their current members and through transferring in of religiously active members from other "competing" conservative churches; to a much lesser extent conversion of the irreligious or defection from liberal churches aids growth (Bibby 2003; Bibby and Brinkerhoff 1993; 1983; 1973). This "circulation of the saints" thesis aptly describes the growing Mainline churches in our study, insofar as they are growing primarily because of transfers from churches that are similar to them denominationally, theologically, or both. 
Building on Bibby's (Bibby 2003; Bibby and Brinkerhoff 1993; 1983 ; 1973) explanation of growth in conservative Churches, in their recent work, Reimer and Wilkinson (2015) add some theoretical heft to the discussion of conservative church vitality. We conclude by giving them the last word. At the core of their theory is the idea that the numerical success of conservative Christian congregations is linked to their emphasis on "external locus of authority" (Reimer and Wilkinson, 2015: 62 ). When a congregation's source of authority is externalized, not subjective and individual, a distinct cultural identity manifests and greater unity of purpose is achieved. In the case of Conservative Protestants (and those resembling them), their collective identity and unity of purposeshaped as it is by immutable Biblical mandate-leads them to focus on formative religious experiences and faith development of youth, both of which are correlated to religious retention and, by extension, growth (2015: 55-62). Again, Reimer and Wilkinson's (2015) theory helps us to further comprehend the unique traits of the growing Mainline churches in our study.

\section{REFERENCES}

Angus Reid Institute. 2015. Religion and faith in Canada today: Strong belief, ambivalence and rejection define our views. Retrieved January 20, 2016 from: http://angusreid.org/faith-in-canada/

Armstrong, Jane. 2011. Report on the results of the United Church of Canada identity survey 2011. Toronto, ON: Jane Armstrong Research Associates.

Barna, George. 2003. Small churches struggle to grow because of the people they attract. Retrieved August 20, 2015 from:

https://www.barna.org/barna-update/5-barna-update/126-small-churches-struggle-to-grow-because-of-the-people-they-attract\#.Vcuw65VRFdg

Bibby, Reginald W. 2012. A New Day: The Resilience \& Restructuring of Religion in Canada. Lethbridge, AB: Project Canada Books.

. 2011. Beyond the Gods and Back. Lethbridge, AB: Project Canada Books.

. 2004. Restless Churches: How Canada's Churches Can Contribute to the Emerging Renaissance. Kelowna, BC: Novalis.

. 2003, April. The circulation of the saints: One final look at how conservative churches grow. Paper presented at the annual meeting of the Pacific Sociological Association, Pasadena, CA.

.2002. Restless Gods: The Renaissance of Religion in Canada. Toronto, ON: Stoddart. 
1999. On boundaries, gates, and circulating saints: A longitudinal look at loyalty and loss. Review of Religious Research 41: 149-164.

. 1993. Unknown Gods: The Ongoing Story of Religion in Canada. Toronto: Stoddart.

. 1987. Fragmented Gods: The Poverty and Potential of Religion in Canada. Toronto: Stoddart.

Bibby, Reginald W., and Brinkerhoff, Merlin B. 1994. Circulation of the saints, 1966-1990: New data, new reflections. Journal for the Scientific Study of Religion 33: 273-280.

. 1983. Circulation of the saints revisited: A longitudinal look at conservative church growth. Journal for the Scientific Study of Religion 22: 253-262.

. 1973. The circulation of the saints: A study of people who join conservative churches. Journal for the Scientific Study of Religion 12: 273-283.

Bouma, Gary D. 1979. The real reason one conservative church grew. Review of Religious Research 20: 127-37.

Brinkerhoff, Merlin B. and Burke Kathryn L. 1980. Disaffiliation: Some notes on 'Falling from the faith.' Sociological Analysis, 41: 41-54.

Bromley, David G. 1988. Falling from the Faith: Causes and Consequences of Religious Apostasy. Thousand Oaks, CA: Sage.

Clarke, Brian and Macdonald, Stuart. 2011. How are Canada's five largest Protestant denominations faring? A look at the 2001 census. Studies in Religion 40(4): 511-534.

. 2007. "Simply 'Christian': Canada's newest major religious denomination," Toronto Journal of Theology 23(2): 109-125.

Demerath, N. Jay III and Yang, Y. 1998. Switching in American religion: Denominations, markets, and paradigms? In Religion in a Changing World, edited by Madeleine Cousineau, pp.3-10, Westport, CT: Praeger.

Finke, Roger and Stark, Rodney. 2005. The Churching of America, 1776-2005: Winners and losers in our religious economy. New Brunswick, NJ: Rutgers University Press.

. 2001. The new holy clubs: Testing church-to-sect propositions. Sociology of Religion, 62: 175-189.

George, Lianne. 2006, July 1. What we believe. Maclean 's, 119(27/28): 35-38.

Government of Ontario. 2016. People and culture. Retrieved January 8, 2016 from:

http://www.ontarioimmigration.ca/en/about/OI_ABOUT_PEOPLE.html

Hadaway, C. Kirk. 2011. FACTS on Growth: 2010. Hartford, CT: Hartford Institute for Religion Research. 
Hadaway, C. Kirk. and Marler, Penny, L. 1993. All in the family: Religious mobility in America. Review of Religious Research 35: 97-116.

Haskell, David M. 2009. Through a Lens Darkly: How the News Media Perceive and Portray Evangelicals. Toronto, ON: Clements Academic.

Haskell, D.M. , Flatt, K., Burgoyne, S. (2016). Theology Matters: Comparing the Traits of Growing and Declining Mainline Protestant Church Attendees and Clergy. Review of Religious Research 58 (4): 515-541.

Haskell, David M., Paradis, Ken, and Burgoyne, Stephanie. 2008. Defending the faith: Reaction to The DaVinci Code, The Jesus Papers, The Gospel of Judas and other pop culture discourses in Easter Sunday sermons. Review of Religious Research 50(2): 139-156.

Iannaccone, Lawrence, R. 1994. Why strict churches are strong. American Journal of Sociology 99: 1180-1211.

Kelley, Dean, M. 1972. Why Conservative Churches are Growing: A Study in Sociology of Religion. New York: Harper and Row.

Kinnaman, David. 2011. You Lost Me: Why Young Christians Are Leaving Church... and Rethinking Faith. Grand Rapids, MI: Baker.

Lippy, Charles, H. 2006. Faith in America: Change Challenge and New Directions, Volume 1. Westport, CT: Praeger.

Marler, Penny, L. and Hadaway, C. Kirk. 1993. Toward a typology of 'marginal members'. Review of Religious Research 35: 34-54.

Martin, David. 1962. The denomination. British Journal of Sociology 13: 1-14.

McKinney, Jennifer and Finke, Roger. 2002. Reviving the Mainline: An overview of clergy support for evangelical renewal movements. Journal for the Scientific Study of Religion 41(4):773-785.

Murphy, Terrence, Perin, Roberto, Chausse, Gilles and Clarke, Brian. 1996. A Concise History of Christianity in Canada. Don Mills, ON: Oxford University Press.

Newport, Frank. 2006. A look at religious switching in America today. Gallup Poll, June 2006. [Data Set]. Gallup Inc. [Distributor]. Retrieved May 16, 2015 from:

http://www.gallup.com/poll/23467/look-religious-switching-americatoday.aspx

Niebuhr, H. Richard. 1929. The Social Sources of Denominationalism. New York: Henry Holt and Company.

Patton, Michael. 1990. Qualitative Evaluation and Research Methods. Beverly Hills, CA: Sage.

Pew Research Center. 2015. America's changing religious landscape. Washington, D.C.: Author. Retrieved May 16, 2015 from: 
http://www.pewforum.org/2015/05/12/americas-changing-religiouslandscape/

Posterski, Don, C. and Barker, Erwin. 1993. Where's a Good Church? Winfield, AB: Wood Lake Books.

Reese, Martha, G. 2008. Unbinding the Gospel: Real Life Evangelism. St. Louis, MO: Chalice.

Reimer, Sam, H. 2003. Evangelicals and the Continental Divide: The Conservative Protestant Subculture in Canada and the United States. Montreal, QC: McGill-Queens University Press.

Reimer, Sam, H. and Wilkinson, Michael. 2015. A Culture of Faith: Evangelical Churches in Canada. Montreal, QC: McGill-Queen's University Press.

Roof, Wade, C. and McKinney, William. 1987. American Mainline Religion: Its Changing Shape and Future. New Brunswick, N.J.: Rutgers University Press.

Sherkat, Darren, E. 2014. Changing Faith: The Dynamics and Consequences of Americans'Shifting Religious Identities. New York: New York University Press.

_ 2001. Tracking the restructuring of American religion: Religious affiliation and patterns of religious mobility, 1973-1998. Social Forces 79: 1459-1493

Smith, Christian and Snell, Patricia. 2009. Souls in Transition: The Religious and Spiritual Lives of Emerging Adults. New York: Oxford University Press.

Stark, Rodney. 1996. Why religious movements succeed or fail: A revised general model. Journal of Contemporary Religion 11(2): 133-146.

Stark, Rodney and Finke, Roger. 2000. Acts of Faith: Explaining the Human Side of Religion. Berkeley: University of California Press.

Stetzer, Ed. 2015. The rise of evangelical nones. Atlanta, Georgia: CNN News. Retrieved June 23, 2015 from:

http://www.cnn.com/2015/06/12/living/stetzer-christian-nones/ index.html?utm source $=$ feedburner\&utm medium $=$ feed\&utm campaign $=$ Feed $\% 3 \mathrm{~A}+\mathrm{rss} \% 2 \mathrm{Fcnn}$ living $+\% 28 \mathrm{RSS} \% 3 \mathrm{~A}+\mathrm{CNN}+-$ + Living $\% 29$

Tamney, Joseph, B., and Johnson, Stephan, D. 1998. The popularity of strict churches. Review of Religious Research 39(3):209-23.

Thiessen, Joel. 2015. The Meaning of Sunday: The Practice of Belief in a Secular Age. Montreal, QC: McGill-Queen's University Press.

United Church of Canada. 2016. Statistics. Retrieved January 8, 2016 from:

http://www.united-church.ca/organization/statistics

Wenger, Jacqueline, and Reese, Martha, G. 2006. Summary of responses for "Survey of Evangelicalism in Mainline Churches": A study of Mainline 
churches performing high numbers of adult baptisms. St. Louis, MO: GraceNet Mainline Evangelicalism Project.

VanGinkel, Aileen. 2003. Evangelical beliefs and practices: A summary of the 2003 Ipsos-Reid survey results. Markham, ON: Evangelical Fellowship of Canada.

Yancey, George A, Reimer, Samuel H, O'Connell, Jake H. 2015. How academics view Conservative Protestants. Sociology of Religion, 76 (3): 315-336.

Yellow Pages Group. 2016. Church phone numbers: Toronto, Ontario. Retrieved January 8, 2016 from:

http://canada411.yellowpages.ca/search/si/1/church/Toronto $\% 2 \mathrm{C}+\mathrm{ON}$

D. Millard Haskell is Associate Professor in the Faculty of Liberal Arts at Wilfrid Laurier University's Brantford Campus. He is cross-appointed to the departments of Religion \& Culture and Digital Media \& Journalism. His research focuses on the social scientific study of contemporary Christianity and religion and media.

dhaskell@,wlu.ca

Stephanie Burgoyne is Assistant Professor in the Faculty of Liberal Arts at Wilfrid Laurier University's Brantford Campus. Specializing in mathematics education, her primary teaching commitment is in the department of Youth and Children's Studies. Her research involves statistical analysis in religious contexts and math pedagogy.

sburgoyne@,wlu.ca

Kevin N. Flatt is Associate Professor of History, Director of Research, and Chair of History and International Studies at Redeemer University College. His research focuses primarily on Christianity in Canada and employs historical as well as social scientific methods.

kflatt@redeemer.ca 